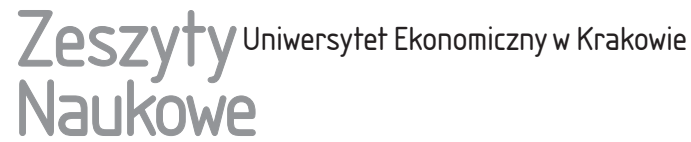

\author{
Magdalena Frańczuk \\ Katedra Prawa Publicznego \\ Uniwersytet Ekonomiczny w Krakowie
}

\section{Podstawy aksjologiczne współczesnej administracji}

\section{Streszczenie}

W artykule przedstawiono główne aspekty związane z problematyką aksjologii administracji publicznej. Poprzez syntetyczną analizę zasad ogólnych Kodeksu postępowania administracyjnego nawiązano do wartości, jakie chronić powinna administracja, oraz do zagadnienia etyki urzędników. Przedstawiono również założenia Europejskiego kodeksu dobrej praktyki administracyjnej realizującego zasadę art. 41 Karty praw podstawowych Unii Europejskiej - prawo do dobrej administracji. Artykuł stanowi przyczynek do szerszej dyskusji nad efektywnymi sposobami budowania zaufania do administracji publicznej zwłaszcza poprzez kształtowanie postaw etycznych służby cywilnej.

Słowa kluczowe: administracja responsywna, prawo, zaufanie, etyka, zasady ogólne.

\section{Wprowadzenie}

Problematyka badawcza podstaw aksjologicznych administracji publicznej według Z. Cieślaka [2000, s. 59] „,ma duże znaczenie praktyczne dla konstruowania administracji i prawa administracyjnego. Właściwe zinwentaryzowanie wartości osadzonych w prawie, gruntowna wiedza o ich relacjach, określenie pól kolizji wartości oraz ich granic dają ustawodawcy użyteczne narzędzie do tworzenia sprawnych układów administracyjnych, a stosującemu prawo ułatwiają interpretację przepisów prawnych. Pogłębiona refleksja aksjologiczna nad teoretycznymi i praktycznymi aspektami tworzenia oraz funkcjonowania administracji publicznej wydaje się obecnie bardzo pożądana". Odnosi się wrażenie, że problematyka 
badań aksjologicznych administracji jest obecna raczej w niewielkim stopniu tak w nauce prawa administracyjnego, jak i w nauce administracji [Cieślak 2000, s. 61].

Celem artykułu jest analiza zbioru podstawowych zasad i wartości, według których administracja powinna postępować i które powinna chronić. Posłużono się pojęciem wartości, odróżniając je od pojęcia zasady, która jest służebna względem wartości.

W ujęciu aksjologicznym wartość jest jedną z podstawowych cech charakteryzujących przedmioty i zjawiska w relacjach z człowiekiem. Stanowi specyficzną postać bytu, która służy do obiektywnej kwalifikacji różnych przedmiotów i zjawisk (por. [Sosenko 1998]). Polski filozof zajmujący się m.in. teorią wartości, A.B. Stępień, określa wartość jako coś cennego lub dzięki czemu coś jest cenne. Definiuje też dobro moralne jako zgodność działania ludzkiego z naturą ludzką [Stępień 1995, s. 240]. Według zaś M. Schelera, jednego z najbardziej znanych aksjologów XX w., wartości zobowiązują moralnie, są obiektywne i normatywne. Pozostają ze sobą we wzajemnych relacjach i tworzą hierarchię. Najniżej w tej hierarchii znajdują się wartości zmysłowe, wyżej wartości witalne, wartości duchowe, a najwyżej wartości religijne, absolutne. Moralność polega na wybieraniu zgodnym z tak ustaloną hierarchią wartości [Scheler 1916, s. 507-513]. Jak wskazuje Z. Cieślak [2014, s. 2], w prawie i prawoznawstwie przyjmuje się zasadniczo słownikowe znaczenie wartości traktujące moralność jako cechę lub zespół cech właściwych danej osobie lub rzeczy, stanowiących o jej walorach cennych dla ludzi, mogących zaspokoić jakieś ich potrzeby. Przyjmuje się też, że wartości nadają normom etyczną prawomocność.

Zasad prawa administracyjnego nie da się analizować w oderwaniu od wartości. Wartości można natomiast wywieść przede wszystkim z zasad ogólnych administracji, dlatego poświęcono im szczególną uwagę. Zasady ogólne administracji uregulowane zostały w rozdziale drugim działu pierwszego kodeksu postępowania administracyjnego. W opracowaniu podjęto próbę refleksji nad tym, jak we współczesnych realiach wartości powinny być brane pod uwagę w procesie szeroko pojętego administrowania. Niniejszy artykuł powinien stać się przede wszystkim przyczynkiem do odpowiedzi na pytania:

- jak w przyszłości powinna kształtować się praktyka administracji,

- w jakim kierunku powinna podążać nauka i praktyka tego działu prawa, aby skutecznie realizować i chronić przewidziane w kodeksie postępowania administracyjnego zasady,

- w jaki sposób realizować wartości, na straży których powinny stać organy administracji publicznej. 


\section{Przegląd podstawowych zasad administracji a realizowane wartości}

\subsection{Zasady ogólne Kodeksu postępowania administracyjnego}

Zasady ogólne prawa administracyjnego zostały uregulowane w dziale I rozdz. 2 Kodeksu postępowania administracyjnego ${ }^{1}$. Zgodnie z art. 6 k.p.a. organy administracji publicznej działają na podstawie przepisów prawa. W przepisie tym wyraźnie nawiązano do zasady państwa prawa w znaczeniu formalnym jako zasady ustrojowej zobowiązującej m.in. podmioty administrujące do przestrzegania i działania w granicach prawa. Jak podkreśla L. Morawski [2005, s. 241, 242], zasada praworządności stanowi podstawę wszystkich państw demokratycznych. Na zasadę tę składa się przekonanie, że sprawowanie władzy musi opierać się na regułach prawa. W ścisłym znaczeniu chodzi o zasadę legalizmu, ponieważ obowiązek przestrzegania prawa skierowany jest do organów państwa. Naruszenie tej zasady zabezpieczone jest sankcją nieważności decyzji, istnieje bowiem przepis pozwalający na stwierdzenie nieważności decyzji wydanej bez podstawy prawnej lub z rażącym naruszeniem prawa (art. $156 \S 1$ k.p.a.) [Żukowski i Sawuła 2012, s. 78]. Wśród gwarantów tak rozumianej praworządności szczególne znaczenie dla administracji mają Naczelny Sąd Administracyjny (kontrolujący zgodnie z art. 184 Konstytucji RP działania administracji publicznej) oraz społeczeństwo obywatelskie.

Zasadę państwa prawa rozwinięto w kolejnych artykułach Kodeksu postępowania administracyjnego, w szczególności w art. 7, który stanowi, że „w toku postępowania organy administracji publicznej stoją na straży praworządności, z urzędu lub na wniosek stron podejmują wszelkie czynności niezbędne do dokładnego wyjaśnienia i załatwienia danej sprawy, mając na względzie interes społeczny i słuszny interes obywateli". Poprzez przywołany przepis ustawodawca chroni przede wszystkim dobro obywateli. Dobro to powinno być respektowane we wszystkich działaniach organów administracji publicznej, co jest bardzo istotne zwłaszcza w kontekście typowej dla administracji relacji hierarchicznej państwo - obywatel. Administracja ma więc z założenia służyć obywatelom, odpowiadać i reagować na konkretne potrzeby. Model administracji responsywnej, jak wskazuje M. Stępień [2008, s. 61], jest nakierowany na odczytywanie i zaspokajanie preferencji, wartości, potrzeb oraz dążeń obywateli.

Równie ważną zasadą, na której powinno opierać się działanie organów administracji publicznej, jest zasada określana we wcześniejszym stanie prawnym jako zasada ,pogłębiania zaufania” do administracji. W obecnym kształcie lepiej

${ }^{1}$ Ustawa z dnia 14 czerwca 1960 r. Kodeks postępowania administracyjnego Dz.U. 1960, nr 30, poz 168 z późn. zm., zwanego dalej k.p.a. 
oddaje istotę funkcji administracji art. 8 k.p.a. Ustawodawca nakłada na organy administracji publicznej obowiązek prowadzenia postępowania „W sposób budzący zaufanie jego uczestników do władzy publicznej”. Przepis ten zatem pośrednio ma za zadanie wzbudzać zaufanie - poprzez administrację - do państwa.

Warto zwrócić uwagę na pojęcie zaufania, do którego bezpośrednio odwołuje się ustawodawca. Jak wskazuje P. Sztompka [2002, s. 132], wśród różnych form zaufania można wyróżnić tzw. zaufanie instytucjonalne do złożonych bytów organizacyjnych angażujących liczne zbiorowości anonimowych uczestników, jak też tzw. zaufanie systemowe kierowane pod adresem całego systemu społecznego i jego uczestników. Istnieją też określone kryteria wpływające na budowę zaufania do danej osoby/instytucji, które można rozpatrywać w kontekście strukturalnym i sytuacyjnym, w którym działa dana osoba czy instytucja. Co się tyczy zasady zaufania do władzy publicznej, które powinno być wzbudzane w efekcie podejmowanych przez organy administracji działań, ważny jest przede wszystkim ów kontekst, w którym organ administracyjny jest osadzony. Jak zauważa P. Sztompka [2002, s. 314], chodzi o to, czy zachowanie takiego podmiotu (darzonego zaufaniem) jest skutecznie monitorowane i kontrolowane, a w konsekwencji zagrożone negatywnymi sankcjami w razie naruszenia zaufania.

Zasada zaufania wiąże się ściśle nie tylko z przepisami dotyczącymi kontroli i nadzoru nad organami administracji publicznej, ale także z możliwością odwołania się od niekorzystnej dla strony decyzji, która zapadła w toku postępowania. Jest ona powiązana z art. 15 k.p.a., z którego wynika wprost zasada dwuinstancyjności uszczegółowiona w art. 16 k.p.a., gdzie wskazano, że uchylenie lub zmiana decyzji ostatecznych, stwierdzenie ich nieważności oraz wznowienie postępowania może nastąpić tylko w przypadkach przewidzianych w kodeksie lub ustawach szczególnych. Decyzje mogą być zaskarżane do sądu administracyjnego z powodu ich niezgodności z prawem na zasadach i w trybie określonych w odrębnych ustawach. Zaskarżanie decyzji wynika zazwyczaj z chęci uniknięcia sankcji, jaką dana decyzja niesie dla strony niezadowolonej z konkretnego rozstrzygnięcia.

Jak wskazuje J. Zimmermann [2013, s. 235], „w prawie administracyjnym pojęcie sankcji jest specyficznie rozumiane i jednocześnie spełnia ono odmienną, bardziej zróżnicowaną rolę niż w innych dziedzinach prawa. Przede wszystkim nie jest ono wyłącznie wiązane z elementami normy prawnej. Słowo sankcja oznacza coś więcej: można tak nazwać wszelkie instrumenty, które powinny zapewnić zrealizowanie przez administrację prawno-administracyjnych założeń celowych. Są to więc odrębne instytucje prawne, za pomocą których administracja publiczna ujawnia swoje władztwo". Organy administracji wydają decyzje, które w pewnych okolicznościach mogą być skutecznie kwestionowane przez podmioty administrowane. Strona ma możliwość monitorowania działań administracji w trakcie postępowania, może kwestionować niekorzystne dla siebie decyzje poprzez zastoso- 
wanie odpowiednich regulacji proceduralnych, a w razie konieczności zastosować środki odwoławcze. Możliwość aktywnego uczestniczenia w postępowaniu administracyjnym daje stronie poczucie bezpieczeństwa, a tym samym buduje zaufanie. Zaufanie, jak wskazuje G. Schwan [2007, s. 132], ,jest zjawiskiem z zakresu teorii demokracji, stanowi fundamentalną kategorię demokracji”. Jest nieodłącznie związane z zasadą państwa prawa, a co za tym idzie z art. 6 k.p.a., który jak wskazano wcześniej, zasadę tę wyraźnie deklaruje. Według K. Kicińskiego [2012, s. 20] efektywne funkcjonowanie administracji zależy właśnie od zaufania, jakim darzą ją obywatele. Zaufanie to wynika zarówno z przekonania, że urzędnicy są dobrymi fachowcami, jak i wiary w to, że dobro publiczne jest dla nich istotne.

$\mathrm{Z}$ przedstawioną problematyką wiążą się również zasady wyrażone w art. 9 k.p.a., zgodnie z którym:

1) organy administracji publicznej są obowiązane do należytego i wyczerpującego informowania stron o okolicznościach faktycznych i prawnych, które mogą mieć wpływ na ustalenie ich praw i obowiązków będących przedmiotem postępowania administracyjnego,

2) organy czuwają nad tym, aby strony i inne osoby uczestniczące w postępowaniu nie poniosły szkody z powodu nieznajomości prawa, i w tym celu udzielają im niezbędnych wyjaśnień i wskazówek.

W powołanym przepisie strona traktowana jest analogicznie do konsumenta. Staje się niejako konsumentem usługi administracyjnej. Jako podmiot słabszy od organu administracyjnego, mającego kompetencje władcze, powinna być należycie poinformowana o przysługujących jej prawach i możliwościach podejmowania określonych działań w toku postępowania. Warto za B. Suchodolskim [2012, s. 153] dodać, że współczesne urzędy administracji publicznej mogą być traktowane jako przedsiębiorstwa usługowe, które powinny przykładać dużą wagę do jakości świadczonych przez siebie usług. Stwierdzenie takie jest uzasadnione chociażby powszechnym użyciem określania „klient administracji” i wprowadzeniem tzw. standardów obsługi klienta w urzędach ${ }^{2}$.

Ponadto wielu autorów podkreśla jak ważny, także w aspekcie etyki administracyjnej, jest dostęp podmiotów administrowanych do informacji i to nie tylko w kontekście realizacji zasady wyrażonej w art. 9 k.p.a. W pracy [Etyczne aspekty działalności... 2004] zauważono, że obywatele są coraz lepiej poinformowani i zarazem coraz bardziej zainteresowani działalnością sektora publicznego. Widoczna jest tendencja do wzrostu przejrzystości funkcjonowania administracji publicznej przez zapewnienie obywatelom dostępu do dokumentów i informacji (wykraczającego poza procedury zwykle zagwarantowane ustawami dotyczącymi

${ }^{2}$ Zob. np. Standardy obsługi klienta w Urzędzie M. St. Warszawy, Załącznik do zarządzenia nr 75/2016 Prezydenta Miasta Stołecznego Warszawy z dnia 26.01.2016 r. 
prawa do informacji). Coraz częściej wymaga się od urzędników konsultowania się z obywatelami poprzez badania opinii czy publiczne przesłuchania, np. w procesie planowania przedsięwzięć publicznych czy podejmowania ważnych decyzji. Aktywność obywatelska stanowi czynnik zniechęcający do korupcji i wszelkiego rodzaju wykroczeń w sektorze publicznym [Etyczne aspekty działalności..., cz. II, 2004, s. 62]. Takie tendencje funkcjonowania administracji publicznej będą również skutecznie realizować zasadę zaufania.

$\mathrm{Z}$ zasadą należytego informowania wiążą się logicznie i wynikają z niej regulacje art. 10 i 11 k.p.a., z których wynika, że 1) organy administracji publicznej obowiązane są zapewnić stronom czynny udział w każdym stadium postępowania, a przed wydaniem decyzji umożliwić im wypowiedzenie się co do zebranych dowodów i materiałów oraz zgłoszonych żądań, przy czym odstąpienie od tej zasady możliwe jest tylko w przypadkach, gdy załatwienie sprawy nie cierpi zwłoki ze względu na niebezpieczeństwo dla życia lub zdrowia ludzkiego albo ze względu na grożącą niepowetowaną szkodę materialną, 2) organy administracji publicznej powinny wyjaśniać stronom zasadność przesłanek, którymi kierują się przy załatwieniu sprawy, aby w ten sposób w miarę możności doprowadzić do wykonania przez strony decyzji bez potrzeby stosowania środków przymusu. W art. 12 k.p.a. wskazano konieczność szybkości i wnikliwości działania organu w toku postępowania administracyjnego, tak aby rozwiązał on sprawę, posługując się możliwie najprostszymi środkami, np. nieskomplikowane sprawy, które nie wymagają zbierania dowodów, informacji lub wyjaśnień, powinny być załatwione niezwłocznie. Organ administracji ma dokładnie i rzetelnie zbadać sprawę, ale powinien zastosować się do zasady szybkości postępowania i działać możliwie sprawnie.

\subsection{Znaczenie zasad}

Pozostałe zasady k.p.a. zostały pominięte z uwagi na brak ich bezpośredniego związku z tematyką opracowania. Omówione zasady należy rozumieć jako reguły czy dyrektywy o charakterze ogólnym, mające podstawowe znaczenie dla całości prawa administracyjnego. Stanowią one urzeczywistnienie wartości, jakie chronić ma administracja. Jak wskazuje J. Zimmermann [2013, s. 92], do grupy wartości tworzonych przez samo szeroko pojęte prawo administracyjne należą również niektóre wartości konstytucyjne. Doktryna prawa administracyjnego formułuje zasady ogólne tego prawa, które mają znaczenie w każdym jego segmencie i oznaczają obowiązek rozwijania jakiejś wartości przez administrację publiczną.

Podstawową wartością wyrażoną przez prawo administracyjne wydaje się dobro człowieka (obywatela), a przede wszystkim dobro wspólne obywateli, które przedkłada się nad interes publiczny. Z tej podstawowej wartości można wypro- 
wadzić kolejne, które są chronione przez przepisy szczegółowe. Wartości te to w szczególności życie i zdrowie obywateli, bezpieczeństwo, sprawiedliwość, natomiast zasady, które służą ich ochronie, to m.in. zasada działania administracji na podstawie przepisów prawa (art. 6 k.p.a.), zasada praworządności i ochrony słusznego interesu obywateli (art. 7 k.p.a.), zasada informowania (art. 9 k.p.a.), zasada czynnego udziału stron (art. 10 k.p.a.), zasada wnikliwego i szybkiego działania (art. 12 k.p.a.).

Powyższe rozważania podsumować można słowami J. Zimmermanna [2013, s. 8]: „,nauka prawa administracyjnego zmierza jednocześnie w zbyt wielu kierunkach, które nie są należycie skoordynowane. Nauka ta zbyt często zajmuje się zagadnieniami bardzo szczegółowymi, związanymi z bieżącym ustawodawstwem, które nie jest doskonałe. Podobne refleksje budzi praktyka działania administracji publicznej, a także praktyka orzecznicza sądów administracyjnych. Na obu tych płaszczyznach widoczne jest zapominanie o pryncypiach prawa administracyjnego, o zasadach, jakie leżą u podstaw tej dyscypliny prawniczej, przez co poszczególne działania organów administracyjnych oraz sądów bywają pozbawione mocnych podstaw, są chwiejne i okazjonalne, poddające się aktualnym modom i trendom politycznym. Prawo administracyjne jest też na tyle odrębne i specyficzne, że przyjmowanie w jego stosowaniu wzorów dyscyplin sądowych jest niebezpieczne, a tego rodzaju tendencje są widoczne w orzecznictwie sądów administracyjnych. Negatywne zjawiska, o jakich mowa, pojawiają się nieraz dla doraźnych celów praktycznych, ekonomicznych, prakseologicznych i nierzadko politycznych, a nawet oportunistycznych. Działa się wtedy tak, jak gdyby zasad prawa administracyjnego nie było, albo wybiera się spośród nich tylko niektóre - te, które w danym przypadku są »wygodniejsze«. W ten sposób nie tylko zaprzepaszcza się wieloletni dorobek doktryny, ale pozbawia się naturalnej bazy dla działań podejmowanych w prawie administracyjnym". Mając na uwadze przytoczoną refleksję, jeszcze wyraźniej należy podkreślić znaczenie „etycznej” administracji jako gwaranta zasad wyrażonych w k.p.a., a przede wszystkim gwaranta wartości wyrażonych przez wspomniane zasady.

\section{Wartości a etyka w administracji}

\subsection{Etyka w administracji}

Kwestią ściśle związaną z realizacją wskazanych wyżej zasad jest etyka administracji publicznej. Aby skutecznie chronić podstawowe zasady i wartości administracji, konieczne jest zachowanie przez jej pracowników pewnych moralnych czy też etycznych standardów. Jednakże nie można oczekiwać, że każdy urzędnik, pracownik służby publicznej, będzie zawsze i w każdych warunkach zachowywał 
się etycznie. Aparat administracyjny jest bowiem zbiorem ludzi, tworzy pewną zorganizowaną hierarchicznie społeczność. Według F. Fukuyamy [1997, s. 37, 38] hierarchia jest niezbędna, ponieważ nie ma gwarancji, że każdy z członków społeczności (w tym przypadku pracowników aparatu administracyjnego) będzie w swym postępowaniu kierował się wyłącznie normami etycznymi. Powstaje zatem konieczność zachowania hierarchii pracowników służby administracyjnej. $\mathrm{W}$ jej obrębie występują jasne reguły postępowania oraz sankcje przewidziane dla tych, którzy tych reguł nie przestrzegają. Inaczej jest w przypadku norm etycznych, gdzie sankcja nie jest sformalizowana i dlatego jest trudniejsza do wyegzekwowania.

Sprawowanie funkcji urzędniczych związane jest bezpośrednio z wykonywaniem władzy nad obywatelami [Czaputowicz 2012, s. 11]. Ważne aby działania nieetyczne urzędników administracyjnych nie znajdowały akceptacji społecznej [Czaputowicz 2012, s. 12]. Obywatele oczekują, że funkcjonariusze publiczni będą przestrzegać standardów etycznych dotyczących uczciwości w sposób bardziej rygorystyczny niż inne grupy zawodowe i że będą oni działać na rzecz interesu wspólnego. Poczynania osób pełniących funkcje publiczne powinny być zawsze z tej perspektywy jawne i przejrzyste, nie powinno być żadnych wątpliwości co do legalności ich działań [Czaputowicz 2012, s. 13]. Przestrzeganie przez administrację zasad etycznych daje bowiem obywatelowi jasność „reguł gry” i stwarza podstawy do zaufania wobec działań podejmowanych w imieniu państwa. Włączenie zasad etycznych w proces budowania etosu urzędów i urzędników publicznych wpływa na zdecydowanie sprawniejsze zarządzanie i rządzenie w państwie. Wynika to z doświadczeń państw, w których istnieje duże zaufanie do administracji i w których na kwestie etyczne zwraca się szczególną uwagę. W tzw. dobrym rządzeniu podstawowe znaczenie mają: otwartość administracji, uczestnictwo, rozliczalność, odpowiedzialność i efektywność [Sakowicz 2012, s. 79]. Przez termin „rozliczalność” (accountability) należy rozumieć jedną z podstawowych funkcji bezpieczeństwa, zapewniającą, że określone działanie dowolnego podmiotu może być jednoznacznie przypisane temu właśnie podmiotowi.

Aby chronić wartości, należy przede wszystkim wykształcić w pracownikach administracji nawyk etycznego postępowania, które według A. Jaroń jest nieodzownym elementem etosu pracy w służbie publicznej, w tym szczególnie w korpusie służby cywilnej. Etyczne postępowanie urzędnika jest także kojarzone z trwałą podstawą dobrze funkcjonującej administracji publicznej [Jaron 2012, s. 128]. Z tego punktu widzenia szczególnie ważne jest ustawiczne kształcenie pracowników administracji, organizowanie szkoleń, kursów i warsztatów. Celem takiego nauczania etyki jest m.in. uświadomienie przyszłym urzędnikom ich odpowiedzialności za wykonywane zadania [Jaroń 2012, s. 130]. Innym celem nauczania etyki administracyjnej, ocenianym z punktu widzenia nie tyle 
urzędnika, ile raczej odbiorcy jego usług, jest zwiększenie zaufania obywateli do administracji publicznej. Realizacji tego celu służą przede wszystkim dostrzegalne cechy charakteryzujące pracę urzędników, ale także wszelkie programy informacyjne dotyczące szkoleń w zakresie etyki pracy urzędnika lub urzędu skierowane na zewnątrz. Jeszcze innym celem jest zwiększenie sprawności funkcjonowania administracji publicznej [Jaroń 2012, s. 130].

\subsection{Chronione wartości}

Zbiór wartości podstawowych dla administracji publicznej tworzą wartości wynikające z kształtu systemu i jego podstawowych założeń ideologicznych, kulturowych, organizacyjnych, a także kultury, tradycji i historii danego społeczeństwa [Celarek 2009, s. 74]. Administracja publiczna swoimi działaniami utrwala wartości, takie jak np. pewność w stosunkach między obywatelami [Sierpowska 2012, s. 82]. Zasadniczą wartością prawa administracyjnego, a jednocześnie wartością, która ma znaczenie w stosowaniu tego prawa, jest sprawiedliwość. Administracja orzeka o prawach i obowiązkach, a więc musi być sprawiedliwa [Zimmermann 2014, s. 121]. W modelu idealnym administracja jest skierowana przede wszystkim na obywatela i jemu ma służyć, ma też budować swego rodzaju zaufane społeczeństwo, które poprzez akty i decyzje administracyjne do niego bezpośrednio się odnoszące tworzy spójną, kierującą się tymi samymi wartościami, całość. Sprawiedliwość można rozumieć jako prawidłowe i słuszne stosowanie i interpretowanie przepisów administracyjnych, a przede wszystkim jako sprawiedliwość proceduralną (zob. więcej: [Zimmermann 2014, s. 122 i nast.]).

Jak wskazuje M. Kasiński [2007, s. 353], w warunkach współczesnego demokratycznego państwa prawa na plan pierwszy wysunąć należy krąg wartości, których respektowanie przez administrację publiczną jest wymogiem konstytucyjnym, ściśle związanym z charakterem tego państwa. Biorąc pod uwagę przepisy obowiązującej Konstytucji RP, utworzyć należy zbiór podstawowych cech dobrej administracji, składających się na jej ustrojowy ideał, w którym znajdzie się:

- administracja respektująca (realizująca) zasadę demokracji i urzeczywistniania sprawiedliwości społecznej, chroniąca niepodległość państwa, wolności i prawa człowieka i obywatela, bezpieczeństwo obywateli, dziedzictwo narodowe i dobra kultury, środowisko, rodzinę i małżeństwo itd.,

- administracja rzetelna (uczciwa),

- administracja społecznie efektywna,

- administracja sprawna, to znaczy w szczególności skuteczna, tania i szybka,

- administracja przestrzegająca przepisów ustaw i innych aktów prawotwórczych pod warunkiem ich zgodności z przepisami konstytucji oraz wyrażonymi w nich wartościami. 
Wśród różnych rodzajów wartości dla administracji szczególne znaczenie mają wartości prakseologiczne, a wśród nich jako najważniejsze Z. Cieślak (podobnie jak M. Kasiński) wymienia: normatywne umocowanie działania, aksjologiczne uzasadnienie działania, maksymalizowanie efektów działania, minimalizowanie kosztów działania, optymalną pojemność kompetencyjną działającego podmiotu, rozdzielność kompetencyjną działających podmiotów, określoność sposobów wewnątrzukładowego oddziaływania, oznaczoność skutków wewnątrzukładowego oddziaływania, rozpoznanie okoliczności działania, wewnątrzukładowe weryfikowanie rozstrzygnięć, domniemanie prawidłowości rozstrzygnięć w układzie, względną trwałość rozstrzygnięć, identyfikację dobra wspólnego, ważenie interesów państwa, wspólnot, obywateli, prawną determinację form pozaukładowego oddziaływania, określoność skutków pozaukładowego oddziaływania [Cieślak 2012, s. 225].

Jednym z przedmiotów administracji jest współżycie społeczne. Administracja ma obowiązek zajmować się sprawami wspólnoty i jej członkami, co oznacza ukierunkowanie administracji na interes publiczny [Celarek 2009, s. 74]. Administracja, realizując funkcje państwa, w konsekwencji polega na bezpośrednim realizowaniu dobra wspólnego. Dobro wspólne pełni funkcję pojęcia narzędzia, wskazując istnienie skonkretyzowanych wartości oraz celów w obowiązujących regulacjach prawnych. Dla pracownika administracji publicznej celem jest realizowanie potrzeb społecznych, gdzie prawo ma być dla niego zarówno środkiem, jak i granicą, której nie może przekraczać [Stadniczeńko 2009, s. 644]. Nie państwo i jego zadania, ale jednostka staje się centralnym punktem w zakresie regulacji administracyjnych [Leoński 1998, s. 2].

\section{Prawo do dobrej administracji - Karta praw podstawowych Unii Europejskiej i Europejski kodeks dobrej praktyki administracyjnej}

\subsection{Uwagi ogólne}

Aby zagwarantować prawidłowe działanie administracji powstały takie akty prawne jak Karta praw podstawowych Unii Europejskiej (uchwalona i podpisana 7 grudnia 2000 r.) $)^{3}$, która wprowadziła m.in. zasady bezstronności postępowania i sprawiedliwości w załatwianiu spraw, oraz Europejski kodeks dobrej praktyki administracyjnej przyjęty przez Parlament Europejski 6 września 2001 r. Jako akt

${ }^{3}$ Moc wiążąca dokumentu została mu nadana przez traktat lizboński podpisany dnia 13 grudnia 2007 r., który wszedł w życie dnia 1 grudnia 2009 r., Karta stanowi obecnie część II Traktatu Ustanawiającego Konstytucję dla Europy. 
niewiążący, o charakterze zaleceń stanowiących konkretyzację obywatelskiego prawa do dobrej administracji wyrażonego w art. 41 Karty praw podstawowych, mający zastosowanie wobec administracji unijnej i administracji poszczególnych krajów członkowskich. Kodeks normuje zasady określające stosunki między instytucjami i urzędnikami Unii a osobami fizycznymi i prawnymi, obejmuje wszelkie kontakty administracji z obywatelem.

Wartości chronione przez prawo administracyjne zostały więc skodyfikowane. Są ujęte w tekstach konkretnych dokumentów, a tym samym zostały sformalizowane. Nie stanowią tylko abstrakcyjnych postulatów, ale realnie istniejące zapisy, które powinny znaleźć się w praktyce stosowania regulacji administracyjnych.

\subsection{Karta praw podstawowych Unii Europejskiej}

Jak wskazuje B. Suchodolski [2012, s. 153, 155], jednym z elementów wysokiej jakości świadczonych usług jest etyczne postępowanie urzędników. W celu zagwarantowania etycznego postępowania urzędników jednostki administracji publicznej coraz częściej opracowują kodeksy etyczne. Urzędy administracji w swojej działalności wypełniają misję społeczną, są organizacjami zaufania publicznego, które świadczą różnorodne usługi dla swoich interesantów. Według I. Lipowicz [2005, s. 111], dobra administracja opiera się na zakotwiczonych w konstytucji wartościach, jest rzetelna, sprawna i efektywna, działa według właściwej podstawy prawnej i w formach prawem przewidzianych, przestrzega procedury administracyjnej, a równocześnie jest elastyczna i odbiurokratyzowana. Jest to pewien ideał, który jako pojęcie niedookreślone zyskał odbicie normatywne w Karcie praw podstawowych Unii Europejskiej ${ }^{4}$.

Art. 41 Karty wprowadził tzw. prawo do dobrej administracji polegające na tym, że:

- każdy ma prawo do bezstronnego i sprawiedliwego rozpatrzenia swojej sprawy w rozsądnym terminie przez instytucje, organy i jednostki organizacyjne Unii. Prawo to obejmuje: a) prawo każdego do bycia wysłuchanym, zanim zostaną podjęte indywidualne środki mogące negatywnie wpłynąć na jego sytuację, b) prawo każdego do dostępu do akt jego sprawy, przy poszanowaniu uprawnionych interesów, poufności oraz tajemnicy zawodowej i handlowej, c) obowiązek administracji uzasadniania swoich decyzji;

- zgodnie z prawem do dobrej administracji - każdy ma prawo domagania się od Unii naprawienia, zgodnie z zasadami ogólnymi wspólnymi dla praw państw członkowskich, szkody wyrządzonej przez instytucje lub ich pracowników przy wykonywaniu ich funkcji;

${ }^{4}$ Karta praw podstawowych Unii Europejskiej (2010/C 83/02), http://eurlex.europa.eu/LexUriServ/ LexUriServ.do?uri=OJ:C:2010:083:0389:0403:pl:PDF, dostęp: 10.03.2015. 
- każdy może zwrócić się pisemnie do instytucji Unii w jednym z języków Traktatów i musi otrzymać odpowiedź w tym samym języku.

Artykuł 41 Karty praw podstawowych ma więc znaczenie przełomowe, ponieważ ostatecznie przeniósł pojęcie dobrej administracji z kręgu pojęć pozaprawnych do kręgu „praw obywatelskich” obywateli Unii Europejskiej. Ale nie tylko im przysługuje to prawo, lecz „każdej osobie”, która domagać się może załatwienia jej sprawy przez organy i instytucje Unii bezstronnie, sprawiedliwie i w odpowiednim terminie. Sam tytuł przepisu i jego miejsce w systematyce Karty wskazuje, że chodzi o prawo obywatelskie i polityczne o mieszanym procesowym i materialno-prawnym charakterze. Prawo do dobrej administracji zawiera w swojej treści zwłaszcza zasadę demokratyzacji administracji, w sensie prawa obywateli do kontroli tego co czyni administracja i generalnie konstytuuje partnerski model relacji między tymi podmiotami. Przepis zatem art. 41 Karty tworzy generalną podstawę publicznego prawa podmiotowego do dobrej administracji [Kasiński 2007, s. 355].

\subsection{Europejski kodeks dobrej praktyki administracyjnej}

Europejski kodeks dobrej praktyki administracyjnej (EKDPA) został opracowany przez Ombudsmana Unii Europejskiej, Jacoba Södermana. We wstępie do EKDPA Europejski Rzecznik Praw Obywatelskich zauważył, że zaszczepienie zasad kultury świadczenia usług w tak zróżnicowanym środowisku pracy, jakim są instytucje UE, nie jest łatwym zadaniem. Europejską służbę cywilną tworzą osoby o różnym pochodzeniu i reprezentujące wiele kultur; ich wizje roli i celów administracji publicznej są bardzo zróżnicowane. Wyzwaniem dla wszystkich instytucji, jest wpojenie wszystkim pracownikom, niezależnie od ich stażu pracy, pozycji i doświadczenia, że kultura świadczenia usług oznacza coś więcej niż tylko przestrzeganie przepisów prawa. Wymaga ona od każdego urzędnika pewnego poziomu autorefleksji i poszukiwania najlepszego sposobu aktywnego wdrażania zasad dobrej administracji na co dzień, a nie tylko unikania błędów niewłaściwego administrowania [Europejski kodeks dobrej praktyki administracyjnej 2014].

Jak wskazuje J. Świątkiewicz [2007, s. 7], kodeks jest interesujący i może przyczynić się do lepszego działania organów administracji oraz stanowić gwarancję skutecznej ochrony praw obywateli i innych podmiotów w relacjach $\mathrm{z}$ organami Wspólnoty Państw. Kodeks nie ma mocy bezwzględnie obowiązującej, ale jego zasady mogą przede wszystkim odegrać pozytywną rolę w usprawnianiu działalności administracji publicznej. Zgodnie z EKDPA każdy obywatel UE ma prawo domagania się od organów i instytucji Unii bezstronnego, zgodnego z prawem rozpatrzenia wniesionej sprawy, bez zbędnej zwłoki. Stosowanie zasad kodeksu ma na celu skuteczniejszą ochronę praw obywateli i innych podmiotów prawa 
oraz sprawniejsze działanie administracji [Co to jest Europejski kodeks dobrej administracji? 2003]. Przepisy EKDPA nakazują urzędnikowi być uprzejmym i kładą duży nacisk na właściwe informowanie obywatela o jego prawach w toku postępowania. Zasadnicze znaczenie kodeks nadaje prawu do dobrej administracji. Każda osoba ma zgodnie z nim prawo do bezstronnego i rzetelnego załatwienia swojej sprawy w rozsądnym terminie. Prawo to obejmuje obowiązek wysłuchania strony przed podjęciem działań, które mogą negatywnie wpłynąć na załatwienie jej sprawy. Zgodnie z EKDPA obywatele mają zagwarantowane prawo dostępu do dokumentów, na organy nałożono natomiast obowiązek uzasadniania decyzji. Mimo że zasada do dobrej administracji z założenia miała służyć samokontroli organu, została uznana za jedno z praw podstawowych [Co to jest Europejski kodeks dobrej administracji? 2003]. EKDPA wprowadza zasady, jakimi powinni kierować się urzędnicy służby cywilnej UE. Są to: zasada oddania Unii Europejskiej i jej obywatelom, rzetelność, obiektywność, szacunek dla innych, przejrzystość. Zasady dobrej praktyki administracyjnej, które wymienia kodeks to: zasada praworządności (art. 4), niedyskryminowania (art. 5), proporcjonalności (art. 6), zakaz nadużywania uprawnień (art. 7), zasada bezstronności i niezależności (art. 8), obiektywności (art. 9), uzasadnionego prawnie oczekiwania konsekwentnego działania i doradztwa (art. 10), zasada uczciwości (art. 11), uprzejmości (art. 12), odpowiadania na pisma w języku obywatela (art. 13), potwierdzania odbioru i wskazania właściwego urzędnika (art. 14), zobowiązanie do przekazania sprawy do właściwej jednostki organizacyjnej instytucji (art. 15), prawo wysłuchania i do złożenia oświadczeń (art. 16), stosowny termin podjęcia decyzji (art. 17), obowiązek uzasadnienia decyzji (art. 18), informacja o możliwościach odwołania (art. 19), powiadomienie o podjętej decyzji (art. 20), ochrona danych (art. 21), prawo składania wniosków o udzielenie informacji (art. 22), prawo do składania wniosków o umożliwienie dostępu do publicznych dokumentów (art. 23), prawo do złożenia skargi do Europejskiego Rzecznika Praw Obywatelskich (art. 26).

Zdaniem M. Kuleszy i M. Niziołek dobre funkcjonowanie państwa zależy w znacznym stopniu od właściwego funkcjonowania administracji publicznej, a zwłaszcza od przestrzegania norm etycznych przez urzędników. Nie wszystko bowiem da się unormować w ustawach. Chociaż to właśnie ustawy wyznaczają wzorzec zachowań ludzkich, także urzędniczych, wiele jeszcze przestrzeni pozostaje dla wzorców etycznych, innymi słowy, przestrzeganie prawa to za mało, trzeba jeszcze osobistej uczciwości funkcjonariuszy publicznych, ich poczucia służby i lojalności wobec konstytucji i państwa [Kulesza i Niziołek 2010, s. 12]. 


\section{Podsumowanie}

„Demokracja to nie jedynie układ instytucji czy konstytucja, nie tylko parlament, nie sam rząd, ani tylko sądy, wszystko to odgrywa bardzo ważną rolę. Jednak demokracja jest przede wszystkim kulturą współistnienia ludzi. Gdyby nie czynniki kulturowe, funkcjonowanie tych instytucji nie byłoby w pełni możliwe, byłoby zapewne wypaczone. Przecież z każdą instytucją związane jest ryzyko, i jeżeli urzędy nie są prowadzone według wypracowanego sytemu, porządnie zgodnie z ich misją, wówczas następuje ich zepsucie. I na odwrót. Jeżeli np. sądy konstytucyjne obchodzą się z konstytucją w sposób odpowiedni, sąd konstytucyjny cieszy się dużym społecznym zaufaniem, pociąga to za sobą duże społeczne poszanowanie społeczeństwa dla samej konstytucji. Gdyby jednak było inaczej, gdyby sądy konstytucji nie szanowały ustawy zasadniczej, to i ona straciła by swoja pozycję w państwie. Tak więc niezwykle ważny jest odpowiedni sposób prowadzenia, zarządzania instytucjami” [Schwan 2007, s. 133].

Najważniejszą kwestą związaną z budowaniem administracji respektującej i realizującej podstawowe zasady przewidziane w kodeksie postępowania administracyjnego jest kładzenie nacisku na normy etyczne już na etapie kształcenia kadr urzędniczych. To bowiem od pracowników służby cywilnej zależy jakość usług świadczonych przez organy publiczne i jej wizerunek wśród obywateli, a zatem wzbudzanie zaufania do administracji, które jest zasadą wyrażoną wprost w art. 8 k.p.a. Administracja w przyszłości powinna być postrzegana jako administracja skierowana na obywatela, pomocna, etyczna, budząca zaufanie do państwa, a zatem w pełni realizująca zasadę państwa prawa. Postulaty takie mogą stać się rzeczywiste jedynie wtedy, gdy większą wagę w procesie administrowania, a wcześniej na etapie nauczania przyszłych administratywistów będzie się przywiązywało do znaczenia kodeksów etyki administracyjnej, które przecież istnieją, ale tak w nauce, jak i w praktyce administracji są spychane na margines, a czasem pomijane. Analizując i stosując przepisy prawa administracyjnego, warto zwracać uwagę na wartości, dla ochrony których ustanowiono dane regulacje. Wartości wyrażone i chronione poprzez zasady prawa administracyjnego to przede wszystkim dobro człowieka i obywatela, które powinno (jeżeli to uzasadnione) przedkładać się nad interes publiczny.

Tak na etapie stosowania prawa administracyjnego, jak też w toku jego nauczania, czy to $w$ formie zajęć uniwersyteckich, czy szkoleń należy zawsze mieć na uwadze te dobra. Tylko należycie zinternalizowane wartości będą realnie chronione i realizowane. 


\section{Literatura}

Celarek K. [2009], Administracja publiczna istotnym elementem w procesie rozwoju społeczeństwa informacyjnego, „Państwo i Społeczeństwo”, Rok IX, nr 3.

Cieślak Z. [2000], Podstawy aksjologiczne administracji publicznej w Polsce - próba oceny, „Studia Iuridica”, XXXVIII/2000.

Cieślak Z. [2012], Nauka administracji, LexisNexis, Warszawa.

Cieślak Z. [2014], Aksjologiczne podstawy jawności. Perspektywa nauk o administracji [w:] Jawność i jej ograniczenia, t. 2: Podstawy aksjologiczne, red. Z. Cieślak, C.H. Beck, Warszawa.

Co to jest Europejski kodeks dobrej administracji? [2003], Urząd Komitetu Integracji Europejskiej, http:/www.cie.gov.pl/WWW/quest.nsf/0/445EBE8FB1B7A6DFC1256E860027FF5A?Open,19.11.2003 r. (dostęp: 15.12.2014).

Czaputowicz J. [2012], Etyka w służbie publicznej [w:] Etyka w służbie publicznej, red. J. Czaputowicz, Krajowa Szkoła Administracji Publicznej, Warszawa.

Etyczne aspekty działalności samorzadu terytorialnego. Poradnik dla samorzadów [2004], red. J. Filek, Małopolska Szkoła Administracji Publicznej Akademii Ekonomicznej w Krakowie, Kraków

Europejski kodeks dobrej praktyki administracyjnej [2014], Europejski Rzecznik Praw Obywatelskich, http://www.ombudsman.europa.eu/pl/resources/code.faces\#/page/1 (dostęp: 20.01.2015).

Fukuyama F. [1997], Zaufanie. Kapitał społeczny a droga do dobrobytu, PWN, Warszawa-Wrocław.

Jaroń A. [2012], Formacja w zakresie etyki przyszłego pracownika administracji publicznej [w:] Etyka w stużbie publicznej, red. J. Czaputowicz, Krajowa Szkoła Administracji Publicznej, Warszawa.

Kasiński M. [2007], Rozważania o dobrej administracji, „Annales. Etyka w życiu gospodarczym", t. 10, nr 1.

Kiciński K. [2012], Tradycyjne wartości polskiej administracji w czasie zmian [w:] Etyka w służbie publicznej, red. J. Czaputowicz, Krajowa Szkoła Administracji Publicznej, Warszawa.

Kulesza M., Niziołek M. [2010], Etyka służby publicznej, Lex a Wolters Kluwer business, Warszawa.

Leoński Z. [1998], Materialne prawo administracyjne, wyd. 2, C.H. Beck, Warszawa.

Lipowicz I. [2005], Prawo obywatela do dobrej administracji [w:] Państwo w służbie obywateli. Księga jubileuszowa Jerzego Świątkiewicza, red. R. Hauser, L. Nawacki, Biuro Rzecznika Praw Obywatelskich, Warszawa.

Morawski L. [2005], Wstep do prawoznawstwa, Dom Organizatora, Toruń.

Sakowicz M. [2012], Zarządzanie a standardy etyczne w urzędzie [w:] Etyka w stużbie publicznej, red. J. Czaputowicz, Krajowa Szkoła Administracji Publicznej, Warszawa.

Scheler M. [1916], Der Formalismus in der Ethik und die materiale Wertethik, Jahrbuch für Philosophie und phänomenologische Forschung, Bd. I u. II, herausgegeben von E. Husserl, Freiburg i. B.- Halle a. d. Saale, Verlag von Max Niemeyer.

Schwan G. [2007], Polityka i zaufanie [w:] Na drodze do wspólnoty kultury prawnej, red. M. Lutter, M. Wyrzykowski, Wydawnictwo Uniwersytetu Warszawskiego, Warszawa. Sierpowska I. [2012], Pomoc społeczna jako administracja świadczaca. Studium administracyjnoprawne, Lex a Wolters Kluwer business, Warszawa. 
Sosenko K. [1998], Ekonomia w perspektywie aksjologicznej, Zeszyty Naukowe Akademii Ekonomicznej w Krakowie, Seria specjalna: Monografie, nr 135, Kraków.

Stadniczeńko S.L. [2009], Etos pracowników zawodów administracji publicznej [w:] Między tradycją a przyszłością w nauce prawa administracyjnego. Księga jubileuszowa dedykowana Profesorowi Janowi Bociowi, red. J. Supernat, Wydawnictwo Uniwersytetu Wrocławskiego, Wrocław.

Stępień A.B. [1995], Wstęp do filozofii, Prace Wydziału Filozoficznego, nr 65, wyd. 3, Towarzystwo Naukowe Katolickiego Uniwersytetu Lubelskiego, Lublin.

Stępień M. [2008], Responsywna administracja publiczna, Wydawnictwo Adam Marszałek, Toruń.

Suchodolski B. [2012], Kodeks etyczny jako narzędzie służace do podnoszenia jakości usług administracji publicznej, Zeszyty Naukowe Uniwersytetu Przyrodniczo-Humanistycznego w Siedlcach, nr 94, Seria: Administracja i Zarządzanie.

Sztompka P. [2002], Socjologia. Analiza społeczeństwa, Znak, Kraków.

Świątkiewicz J. [2007], Europejski kodeks dobrej administracji, wyd. VI, Biuro Rzecznika Praw Obywatelskich, Warszawa.

Zimmermann J. [2013], Aksjomaty prawa administracyjnego, Lex a Wolters Kluwer business, Warszawa.

Zimmermann J. [2014], Prawo administracyjne, Lex a Wolters Kluwer business, Warszawa.

Żukowski L., Sawuła R. [2012], Postępowanie administracyjne, wyd. III, Wyższa Szkoła Prawa i Administracji, Przemyśl-Rzeszów.

\section{The Axiological Foundations of Modern Administration}

(Abstract)

The paper presents the main aspects of axiology in public administration. Through synthetic analysis of the general principles of the Administrative Code, the paper discusses the values which should protect public administration, analyses the ethics of officials in administration, and briefly presents the assumptions of the European Code of Good Administrative Behaviour implementing the principle of art. 41 of the Charter of Fundamental Rights of the European Union - the right to good administration. This paper contributes to the broader discussion on effective ways to build confidence in public administration, especially through the development of ethical attitudes in civil servants.

Keywords: responsive administration, law, trust, ethics, general principles. 